\title{
Implementation of Teaching Materials Based on Indonesian Culture in BIPA Learning As One Way to Lift Indonesian Culture in the World
}

\section{Cahyani1 and D. Hadianto ${ }^{2}$}

${ }^{1}$ Faculty of Education of Indonesia, Indonesia University of Education, Jalan Setiabudhi No 229, Bandung, West Java 40154, Indonesia

${ }^{2}$ Postgraduate Program, Indonesia University of Education, Jalan Setiabudhi No 229, Bandung, West Java 40154, Indonesia

\section{Abstract}

This study aims to develop various teaching materials as well as lifting Indonesian culture through bringing the learning of the Indonesian language to the eyes of the world through BIPA learning. The method used in this research is research and

Corresponding Author:

I. Cahyani

isahcahyani@upi.edu

Received: 6 April 2018

Accepted: 3 May 2018

Published: 26 July 2018

Publishing services provided by

Knowledge $\mathrm{E}$

(c) I. Cahyani and D.

Hadianto. This article is

distributed under the terms of

the Creative Commons

Attribution License, which

permits unrestricted use and

redistribution provided that the

original author and source are

credited.

Selection and Peer-review under the responsibility of the ISLLE 2017 Conference Committee.

\section{G OPEN ACCESS} development. Researchers create teaching materials using various cultural terms from various regions in Indonesia, try them out with BIPA learners and make improvements to their shortcomings. The cultural materials used by the author in the mid-level BIPA textbook are a habit, a character from the area, traditional food, traditional clothing, rituals/ traditions, traditional dance, and traditional musical instruments. The results of this study indicated that the authors created unique BIPA teaching materials at intermediate level (B2) and succeeded in making BIPA learners more interested in learning Indonesian. In this way, learners can not only learn BIPA in terms of the Indonesian language but can also simultaneously get to know the culture of Indonesia.

Keywords: instructional BIPA materials, intermediate level (B2), learning BIPA, terms in Indonesian culture

\section{Introduction}

Learning is an activity that is inseparable from human life. Learning is an activity that a person undertakes in order to achieve the desired competence. Through the learning process one can gain better knowledge, skills, and attitudes. The learning process is basically conducted to enhance ability or personal competence [1-3]. Learning is a deliberately designed process to create individual learning activities $[1,4,5]$. Learning is a series of activities that are deliberately created with the intention of facilitating the learning process, while BIPA itself is a term used in language learning that is devoted 
to foreigners. Thus, BIPA learning is an Indonesian language study devoted to foreign speakers [1].

The interest of foreign learners in learning Indonesian differs depending on whether it is related to tourism, education, employment, or business. Apart from these various interests, the main objective of foreign learners in learning the Indonesian language is to communicate using Indonesian well and correctly. BIPA learners differfrom student learners at school $[6,7]$. The average BIPA learners are at the adult age level, so the material used in the content of learning is clearly different from the content in the learning materials in the general schools. This means that it is a challenge for BIPA activists to create interesting BIPA teaching materials or textbooks with the aim of making BIPA learners interested in learning the Indonesian language.

Researchers proposed that one of the ways of making the teaching materials used in BIPA learning interesting is to develop teaching materials that have cultural content. According to Koentjaraningrat [8], Aggarwal [9] and Allen [10], the basic word for "culture" comes from sansakerto buddhayah, the plural form of buddhi meaning "mind." Thus Koentjaraningrat defines culture as a "power of mind" in the form of creativity, intention, and taste, while culture is the result of creation, intention, and taste. Koentjaraningrat explains that basically many differentiate between culture and culture, where culture is a compound development of cultivation, which means the "power of the mind." In the study of anthropology, culture is considered an abbreviation of a culture that is no different from the definition [11-13]. Thus, culture or abbreviated culture, according to Koentjaraningrat, is the whole system of ideas, actions, and the work of human beings in the framework of the life of society that made the human self by learning.

The culture chosen for BIPA teaching materials in this research is represented by habits, figures from certain areas, traditional food, traditional dress, rituals/traditions, traditional dance, and traditional musical instruments. This culture is used in every component of learning BIPA, namely learning to read, write, listen, and speak. The purpose of the use of Sundanese culture in this BIPA learning is that BIPA learners are more attractive in the eyes of learners BIPA as well as the fact that it helps BIPA learners to achieve their goals. These teaching materials can be regarded as a medium or tool to help learners learn the Indonesian language. 


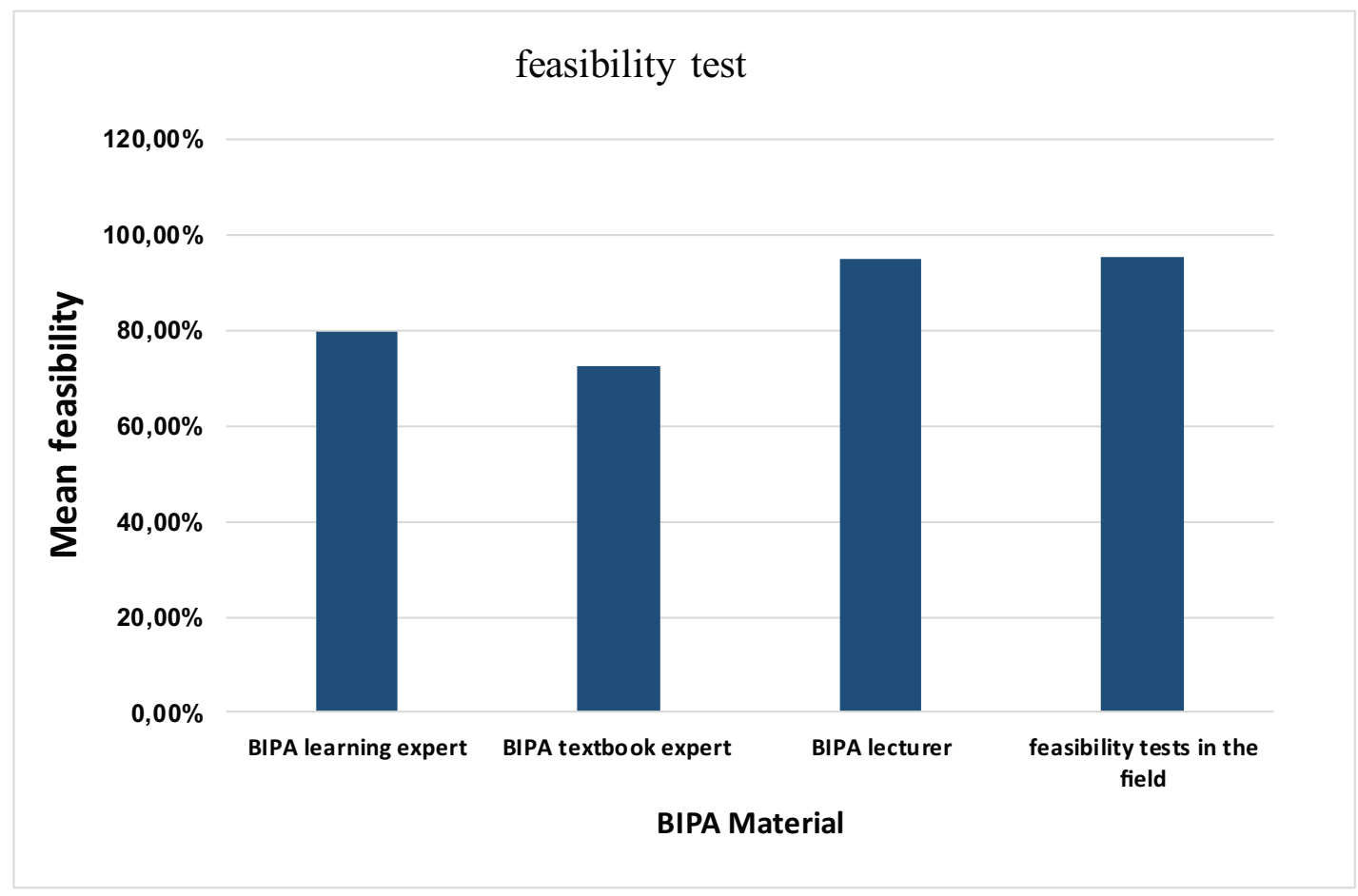

Figure 1: Results of product validation.

\section{Methodology}

This research uses the research and development research method of Borg and Gall [14]. R\&D research, according to Borg and Gall, consists of 10 steps. However, due to time and research limitations, the researchers use six steps, but the core remains reflected in this study. The following steps are carried out by the researchers: (1) conducting the analysis of the product to be developed; (2) planning; (3) developing the initial product form; (4) validating the experts; (5) conducting the product trial; and 6) making product revisions (based on suggestions and field test results).

At the development stage the procedures carried out are the preliminary/predevelopment stage, development procedures, field tests, and revisions. In the preliminary/pre-development stage the researcher conducts product analysis, theoretical studies, and an analysis of previous research studies. At the development stage the researcher develops the initial product form. After the initial product is developed, the next step/stage is to test the product and the last is the product revision. The data collection instruments used in this research are (1) the program observation guidance, (2) the interview questionnaire guides to the BIPA teachers, and (3) the input formats of the experts. The questionnaire use a Likert scale with four alternate answers. The Likert scale can be seen in the table below. 
TABLE 1: Measurements with Likerts scale.

\begin{tabular}{|c|c|c|}
\hline No & $\begin{array}{c}\text { Measurements with Likert } \\
\text { Scale Assessment Results }\end{array}$ & Evaluation Results \\
\hline 1 & 4 & Strongly agree \\
\hline 2 & 3 & Agree \\
\hline 3 & 2 & Disagree \\
\hline 4 & 1 & Strongly disagree \\
\hline
\end{tabular}

The data collected in this study are in the form of quantitative data and qualitative data. The qualitative data comprise information about the feasibility of BIPA materials from (1) BIPA learning experts, (2) BIPA textbook experts, and (3) BIPA practitioners/teachers. The technical data analysis in this research is in the form of qualitative and quantitative analysis. Qualitative analysis is done through various data collection steps ranging from the results of interviews and observation, to organizing, sorting, and classifying data that have been obtained based on the test group, and analyzing and formulating analysis conclusions as a basis to take action toward the production of developed material. Qualitative analysis is used to analyze data that qualitative data that is the result of interviews and observation. Meanwhile, quantitative analysis is used to calculate the presentation of answers to each question posed in the assessment questionnaire $[15,16]$. Questionnaire data processing obtained from questionnaires to validate foreign experts, practitioners, and students is analyzed by using the following formulae [17-19].

The formula for processing data per item:

$$
Q=\frac{X}{X i} 100 \%
$$

Description: Q: percentage, $X$ : respondent's answer in one item, $X i$ : ideal value in one item $100 \%$ constants.

The formula for processing the data as a whole

$$
P=\frac{\sum X}{\sum X i} 100 \%
$$

Information: $\mathrm{P}$ : percentage, $\Sigma x$ : total number of respondents in all items, $\Sigma x i$ : total number of ideal scores in one item 100\%: constants

\section{Findings and Discussion}

Based on the research results, it is very feasible to use this teaching material. This is evident from the percentage of feasibility test results according to BIPA study 
experts, BIPA textbook experts, BIPA teachers, and feasibility tests in the field. The results of analysis of whole aspect learning expert BIPA, reaching percentage $79.88 \%$. The results indicate that this BIPA textbook product have qualification feasible to be applied. The results of the analysis according to the BIPA textbook expert overall reached $72.61 \%$. The results show that it is quite feasible to use this book in BIPA learning. However, improvements are still needed based on expert advice and comments. The result of analysis of all aspects according to the BIPA lecturer reached $94.86 \%$. This result indicates that it is very feasible to apply this BIPA textbook product. The result of analysis based on feasibility tests in the field as a whole aspect reached $95.31 \%$. This result indicates that this BIPA textbook product has a very feasible qualification

The presentation of the material in this book uses the communication-intensive approach [20] in which each aspect of language learning, i.e. reading, writing, listening, and speaking, is not separated but incorporated into one unity and communicative. The purpose of the authors in presenting the learning material in a communicationintensive way is that BIPA learners do not feel they are ordered to learn to read, write, listen, and speak but BIPA learners is learning a unity simultaneously. As an example, when a learner is learning to read the researcher also includes exercises to review the results of the reading by using the language of the learners themselves.

The order of presentation of the material in this book is as follows. The book begins with a cover, a middle-level syllabus, the introduction of letters and numbers, concept maps, and entry into units. Each unit starts with concept maps, followed by learning objectives, context building, language competence, grammar, and cultural notes, and ends with a glossary. The concept maps are used as a general overview of what the BIPA learners will learn. Context building is used as an introduction to the learning materials so that BIPA learners know what they will learn. Language competence consists of reading, writing, listening, and speaking, but in this book the researchers do not separate these. The appropriate approach used by the author in making this book, i.e. communication-intensive, language competence in this book together with the naming of activities and exercises. One activity contains at least two aspects of language competence in each exercise.

\subsection{Results of product feasibility test according to BIPA learning expert}

Based on the test of BIPA learning experts the data obtained on the average feasibility of material selection aspects reached $87.5 \%$. The average language eligibility rate is 
$75 \%$. The average feasibility aspect of ease of understanding material reaches $91.66 \%$. The average of the evaluation aspect of textbook concept comprehension is $80 \%$. The average of the material aspect in the textbook is $75 \%$. The average feasibility of the interactivity aspect of the presentation of the problem reached $75 \%$. The average feasibility of the product feasibility aspect used in the learning to reach $75 \%$. The results of the whole aspect analysis reached $79.88 \%$. The results indicate that this BIPA textbook product has qualified to be applied.

\subsection{Results of product feasibility test according to BIPA textbook expert}

Based on the expert test of the BIPA textbook, the average feasibility aspect of material description is $66.66 \%$. The average feasibility aspect of technique is $66.66 \%$. The average feasibility of the presentation aspect is $75 \%$. The average feasibility of the language form aspect reached $75 \%$. The average eligibility aspect of book views reached $75 \%$. The feasibility average of book worthiness is $75 \%$. The average feasibility of the quality aspect reaches $75 \%$. The results of the overall analysis reached $72.61 \%$. The results show that it is quite feasible to use this book in BIPA learning. However, improvements are still needed based on expert advice and comments.

\subsection{Results of product feasibility test according to BIPA practitioner/lecturer}

Based on the practitioner's test, the average feasibility aspect of the book presentation is $91.66 \%$. The average feasibility of the illustration aspect, picture/photo used reach $100 \%$. The average eligibility of material selection reaches $87.5 \%$. The average feasibility aspect reaches $100 \%$. The average feasibility of evaluation in textbooks reaches $90 \%$. The average eligibility aspect of the book reaches $100 \%$. The result of the whole aspect analysis is $94.86 \%$. These results indicate that it is very feasible to apply this BIPA textbook product.

\subsection{Feasibility test results in the field}

Based on the field test, the average feasibility aspect of the book display aspect reached $93.75 \%$. The average feasibility of the content/material aspect reached 
$96.87 \%$. The result of the whole aspect analysis is $95.31 \%$. The results indicate that this BIPA textbook product is highly qualified to be applied.

\section{Conclusion}

Based on the above explanation, BIPA teaching materials that use cultural elements can encourage learners to be more enthusiastic in following BIPA learning because they think Indonesian culture is very interesting and unique for them. This culturebased BIPA textbook is eligible to be used as a supplement or complement in BIPA learning. This matter cannot be separated from the results of observation of practitioners of BIPA. Learning BIPA by incorporating elements of Indonesian culture in all aspects of language skills not only makes students more interested but is also one way for Indonesia's famous culture to attract tourists to Indonesia.

This prototype of BIPA culture-based teaching materials can be utilized by BIPA organizers. Both teachers and students will be greatly helped by this book in making learning BIPA more interesting. In terms of development, this product still has limitations and is not yet perfect so it still requires further development. Teachers are advised to develop the material that is in the prototype of BIPA's teaching materials so that the learning in the classroom becomes richer. In the development of the BIPA program, the prototype of BIPA teaching materials can be used as one BIPA textbook prototype.

\section{References}

[1] Pribadi B: Model desain sistem pembelajaran [Model of learning system design]. Jakarta: Dian Rakyat; 2009.

[2] Jenkins PC: Exploring the learning process. Teach Learn Nurs. 2010; 5: 157-159.

[3] Papini MR: Pattern and process in the evolution of learning. Psychol Rev. 2002; 109: 186-201.

[4] Galef BG, Heyes CM: Social learning and imitation. Learn Behav. 2004; 32: 3p.

[5] Oblinger DG: Learning spaces. USA: Educause; 2006.

[6] Felder RM, Henriques ER: Learning and teaching styles in foreign and second language education. Foreign Lang Ann. 1995; 28: 21-31.

[7] Levitt B, March JG: Organizational learning. Annu Rev Sociol. 1988; 14: 319-338.

[8] Koentjaraningrat: Kebudayaan mentalitas dan pembangunan [Culture of mentality and development]. Jakarta: PT. Gramedia Pustaka Utama; 2000. 
[9] Aggarwal CC: Data mining: the textbook. New York: Springer International Publishing; 2005.

[10] Allen HW: Textbook materials and foreign language teaching: perspectives from the classroom. The NECTFL Rev. 2008: 62; 5-28.

[11] Imada T: Cultural narratives of individualism and collectivism: a content analysis of textbook stories in the united states and japan. J Cross-Cultural Psychol. 2012; 43: 576-591.

[12] Pickering M: Research Methods for Cultural Studies. Edinburgh: Edinburgh University Press; 2008.

[13] Porat D: Alt's not written here, but this is what happened: students' cultural comprehension of textbook narratives on the israeli-arab conflict. Am Edu Res J. 2004; 41: 963-996.

[14] Borg WR, Gall MD: Educational research: an introduction. England: Longman; 1983.

[15] Cohen L, Manion L, Morrison K: Research methods in education. United Kingdom: Routledge; 2013.

[16] DeFusco RA, McLeavey DW, Pinto JE, Runkle, DE: Quantitative investment analysis workbook. United States: John Wiley \& Sons; 2010.

[17] Arikunto S: Prosedur penelitian: suatu pendekatan praktik [Research procedure: a practice approach]. Jakarta: Rineka Cipta; 1998.

[18] Connolly P: Quantitative data analysis in education: a critical introduction using SPSS. United Kingdom: Routledge; 2007.

[19] Rourke L, Anderson T: Validity in quantitative content analysis. Educ Technol Res Dev. 2004; 52: 5-18.

[20] Widodo: Pengembangan bahan ajar mata kuliah BIPA [Development of BIPA subject materials]. Malang: Malang State University; 2010. 